\title{
Histories of Technology and the Environment in Post/Colonial Africa: Reflections on the Field
}

\author{
Ute Hasenöhrl (D)
}

Citation: Hasenöhrl, U. Histories of Technology and the Environment in Post/Colonial Africa: Reflections on the Field. Histories 2021, 1, 122-144. https://doi.org/10.3390/

histories 1030015

Academic Editor: Jon Mathieu

Received: 4 May 2021

Accepted: 22 June 2021

Published: 10 August 2021

Publisher's Note: MDPI stays neutral with regard to jurisdictional claims in published maps and institutional affiliations.

Copyright: (C) 2021 by the author. Licensee MDPI, Basel, Switzerland. This article is an open access article distributed under the terms and conditions of the Creative Commons Attribution (CC BY) license (https:// creativecommons.org/licenses/by/ $4.0 /)$.
Department of History and European Ethnology, University of Innsbruck, Innrain 52, 6020 Innsbruck, Austria; ute.hasenoehrl@uibk.ac.at

\begin{abstract}
Much has happened since Dipesh Chakrabarty, at the turn of the millennium, paradigmatically called for a "provincialization of Europe". The paper connects with three major trends in current history of technology, exploring these threads with regards to the Global South in general and post/colonial Africa in particular: (1) exemplifying and (later) disentangling transnational connections; (2) rethinking (colonial) infrastructures; and (3) exploring technologies-in-use, everyday practices and perceptions. Unpacking established Science and Technology concepts such as Thomas P. Hughes "Large (Socio)Technical Systems" (LTS) approach for post/colonial contexts, the paper argues that we need to move beyond the much-invoked "key figures" and drivers of global technological (ex)change and scrutinize place- and time-specific landscapes of technology instead. In particular, we need to pay closer attention to seemingly peripheral actors and actants as well as to the manifold interrelations between the human and the "natural" world.
\end{abstract}

Keywords: history of technology; environmental history; post/colonialism; Africa; Global South; eurocentrism; entanglements; infrastructures; large (socio)technical systems; technologies-in-use

\section{Introduction}

Much has happened since Dipesh Chakrabarty, at the turn of the millennium, paradigmatically called for a "provincialization of Europe" [1]. Global history has experienced an unprecedented boom in the last decades [2,3], mirroring topical experiences of intensifying global connections and entanglements, and sparking a "global turn" in many historical sub-disciplines, most prominently in history of Science and Technology. Tracing the manifold flows of knowledge, ideas, technology, goods, organisms, capital, or people across the globe and exploring their impact on different societies and environments, the history of technology has started to question some of its core assumptions and directions, particularly its traditional focus on "Western" actors and technologies. Within these discourses, history of technology of the Global South in general and the legacies of European colonialism in particular have received increasing attention-both with regard to Asia and Africa, as the growing body of scholarly literature and critical studies demonstrate [4] ${ }^{1}$.

Taking off from some brief reflections on the older "Tools of Empire" school of thought and the problem of eurocentrism, my paper connects with three major trends in current history of technology, exploring these threads with regards to the Global South in general and post/colonial Africa ${ }^{2}$ in particular: (1) exemplifying and (later) disentangling transnational connections; (2) rethinking (colonial) infrastructures; and (3) exploring technologies-in-use, everyday practices and perceptions. These areas of study have all experienced significant efforts in recent years to rethink their central assumptions, originating in the need to adapt existing theories and methods to the (historical) realities of the Global South. Unpacking established Science and Technology concepts such as Thomas P. Hughes "Large (Socio)Technical Systems" (LTS) approach for post/colonial contexts, the paper argues that we need to move beyond the much-invoked "key figures" and drivers of global technological (ex)change and scrutinize place- and time-specific landscapes of technology instead, 
regardless of labels such as Western or non-Western, "modern", "traditional", or "hybrid". In particular, we need to pay closer attention to the micro level of transnational networks and transfers, to seemingly peripheral actors and actants, to the plurality of technological practices and experiences "on the ground", as well as to the manifold interrelations between the human and the "natural" world.

Starting off from a history of technology perspective, the paper thus also argues for contextualized histories of technology that not only deconstruct the "social construction of technology" (SCOT), but also situate technologies within larger socio-environmental nexuses and networks. Numerous studies have investigated such "enviro-tech" relations in and for Europe and North America $[5-8]^{3}$. With regard to post/colonial Africa, however, history of technology and environmental history were (and are) rarely written as joined projects despite their overlapping interests (with notable exceptions in the literature on urban sanitation or the construction of large multi-purpose dams) [9-20]. There is still much to be learned, though, on how (colonial, but also indigenous) technologies and practices influenced and shaped natural and social environments-and vice versa, from (inadvertent) enviro-technical feedback loops (e.g., the spread of non-indigenous species along extended networks of transport) and eco-cultural commodity frontiers to the workings of what might be called the "colonial metabolism".

\section{Moving beyond the "Tools of Empire" Narrative-Problems of Eurocentrism in Histories of Technology in the Global South}

Writing post/colonial histories of technology (and the environment) is an open and sometimes contested field. In many ways, David Arnold's plea from 2005 for a "more interactive, culturally-nuanced, multi-sited debate" [21] (p. 85) on technologies (and, we might add, the environment) in the non-Western world is still as relevant today as it was fifteen years ago. There is overwhelming consensus that the discipline needs to move beyond the grand narratives of the past [21-25]. Yet despite having been declared dead and obsolete uncountable times, the "Tools of Empire" narrative in its many variations still looms large, overshadowing more comprehensive takes on how technologies influenced societies and environments in colonial contexts.

Following Daniel Headrick's seminal work from 1981 [26], the "Tools of Empire" narrative tells the story of how European colonial powers-utilizing modern technologies and techniques such as steam engines, machine guns, or quinine prophylaxis-managed to subjugate and exploit indigenous people and nature. In this tradition, (Western) technologies are primarily regarded as instruments of power, enabling European colonial rule both in practice and ideologically. As Michael Adas has argued in his influential study on "Machines as the Measure of Men" from 1989 [27], "superior" European technologies were framed as evidence for the overall superiority of the European people-and the spread of Western technological "marvels" was supposed to legitimize colonial rule as part of Europe's "civilizing mission" [28]. In accordance with the "Tools of Empire" narrative, environmental history has produced its own classic interpretations, highlighting the devastating ecological consequences of colonialism, but also how these colonial experiences sparked the emergence of ecological thinking [14,29-34] $]^{4}$. In contrast to the European hunger for colonial commodities and resources-as well as in reaction to colonial devaluations of Africans / Asians as unfit custodians of nature-indigenous environmental practices were often depicted as being in harmony with nature, a romantic narrative also found in earlier subaltern studies [35-38 $]^{5}$.

These narratives were and are compelling, offering a coherent set of explanations not only for the historical dynamics of colonialism, but also mirroring current concerns with globalization and aggressive turbo-capitalism in the Anthropocene. With their enlightened agenda, they were crucial for developing a critical understanding of Europe's imperial legacies, dispensing with the idea of technological modernity as a universally beneficial process. Yet, despite their merits as progressive pioneers of the field, the "Tools of Empire" school is still caught up "in a modernist view of the world, framing Western technologies and actors 
as the decisive driving forces in the invention and spread of artefacts and systems. As a consequence, it largely interprets global technological (ex)change as dissemination from the top, implicating linear power relations with the colonized as passive recipients" [39] (pp. 363-364). Concentrating on key Western technologies, actors, and contexts, the narrative of Western technologies destructive impact on non-Western societies and environments is therefore still often part of the traditional story of European expansion "from the West to the rest" [40].

Global history has reflected intensively on how to circumnavigate —or at least defusethe problem of replicating such Eurocentric narratives $[1,41,42]^{6}$. Considering their rapid spread since the 18th century as well as their profound impact on life on earth, it is easily comprehensible why scholars and scientists might wish to investigate the global transfer and utilization of Western technologies and infrastructures. Even within microhistories exploring local technological landscapes, reactions to Western technologies are often pivotal points of interest [43]. It is very rare that the tables are turned, with transfer processes towards Europe-or ones that bypass the Western world entirely-as the center of attention. This approach has been implemented most successfully in the historical research on pre-modern societies, particularly China $[44]^{7}$. For post/colonial Africa, there are fewer examples, mostly focusing on indigenous medical, agricultural, or technological knowledge and practices [45-49]. The question of how to cut the Gordian knot of eurocentrism in studies on post/colonial societies where access to, decisions on, and usage of technologies and natural resources were deeply suffused by asymmetries of power remains a conundrum without readily applicable answers. As a matter of fact, even usage of the term post/colonial itself-if not applied in a strictly chronological sense, but also as an analytical concept-might be regarded as problematic, since it reduces African societies to their post/colonial relations, negating the various influences that also shaped African life-from external drivers such as the Cold War to internal social and power struggles [50] (pp. 230-231).

Problems of eurocentrism not only permeate choices of topics and terminology, but also infuse methods, theories, and-last but not least—questions of sources. As Hyungsub Choi has shown for SCOT (Social Construction of Technology) and the appropriation of technologies in post-war South Korea [51], not all concepts and approaches developed for and within Western societies might be successfully transferred to non-Western contexts. Hughes influential notion of "Large (Socio)Technical Systems" (LTS) that has informed many Science and Technology Studies on infrastructural development is another case in point-one I will discuss in detail later in the paper. Suffice to say that many supposedly "universal" explanations and approaches lose considerably in explanatory power when applied to the present and historical realities of the Global South.

Even more demanding is the question of sources. For the colonial period, most records preserved in national or state archives stem from the colonial administrations themselves. In these materials, indigenous voices are often limited to the educated elites or-as time passes - the middle-classes, and primarily reflect the interactions between colonizers and colonized [52,53]. While less limited in their thematic scope, non-official sources such as newspapers, literature, memoires, art, or correspondence - even the ones written in vernacular languages - tend to replicate this class-bias. Subaltern voices-particularly of rural dwellers-are frequently missing. If their concerns and spheres of life are touched at all, they are often depicted through intermediary representation, for example, by actors that speak about, or for (rather than with), the subaltern [54] ${ }^{8}$. While it is a universal truth that historians need to brush their sources against the stroke to reveal implicit meanings and voids as well as their more up-front content, this is even more of a necessity in post/colonial contexts. For contemporary history, a good way to access non-elite African experiences and perspectives is oral history [55-57]. As a matter of fact, many historians have utilized oral histories interviews with contemporaries or memory keepers in a creative way in order to supplement, or compensate for a lack of, written records [58-61]. In addition, social histories have often drawn on court records to explore social conflicts and tensions between 
social groups 9 . History of technology and the environment offers another set of nonwritten sources for interpretation—artefacts, buildings, infrastructures, landscapes, etc. As relicts of the past, sometimes shaped and reshaped over generations in multiple historical contexts, these objects give insights not only into the materiality of the past (including texture, smell, and sound), but also into concrete everyday practices and imaginaries.

There has been much concern within the area studies that the current trend for global histories might result in a new historiographical colonialism [62], with Western scholars and scientists—as academic gold-diggers—seeking out previously "untouched" (re)sources and imposing their interpretations on non-Western histories ([63] on global history and Africa history). There is more than a grain of truth in these concerns. Many historians interested in exploring post/colonial histories of technology and the environment are not from the Global South (myself included) - and even those that are have often experienced much of their academic socialization at the prosperous (and prestigious) universities of Europe or North America [64]. As a result, the discourses and concepts of Western academia structure and shape much of our expectations and thinking when investigating post/colonial histories-a significant bias we should be acutely aware of when active in the field.

Despite these general reservations, history of technology and the environment in the Global South stands out as a particularly vibrant field of study, taking up established threads and discussions and - sometimes gently, sometimes firmly—brushing them against the stroke. The three topics explored in the next sections (networks and connections, colonial infrastructures, and everyday practices and perceptions) are cases in point. Even though, empirically, research has so far only managed to scratch the surface with regard to post/colonial Africa, conceptually, these areas of study have all experienced significant efforts to rethink their central assumptions and widen their objects of study. As a matter of fact, some of the most interesting conceptual interventions in the field stem from post/colonial research, originating from the need to adapt existing theories and methodologies to the (historical) realities of the Global South.

\section{Exchanges, Transfers, and Networks-Writing Post/Colonial Histories of Technology and the Environment as Histories of Entanglements}

Exploring exchanges, transfers, and entanglements is at the very heart of global history as a field of study $([39,65]$ on the state of the art). With regard to the Global South, however, many histories initially utilized rather simplistic models of trans- and international exchange. In lieu with modernization theory's proclivity for linear relations, the political and technological hotspots of Europe and North America were framed as both the starting and target points of imperial networks of power and exploitation that radiated outwards from the metropole towards the farthest reaches of the globe $[26,66-68]^{10}$. This classic "spokes of the wheel" concept of transfer with the Western/colonial metropole at the heart of tightly-controlled imperial networks is now generally regarded as outdated, as it does not do justice to the dynamics and complexities of transnational connections [69-73].

Many questions remain, though, on how specific networks were constructed and functioned over time, who was part of these connections, and how we might best (re)construct these complex relations on the conceptional level. In the following, I will highlight two particularly promising approaches, actor-centered network analysis and the exploration of the "colonial metabolism". I also argue that we need to pay closer attention to the micro level of such transnational networks and transfers. In particular, we need to move beyond the much-invoked "key figures" and drivers of global exchange and pay closer attention to seemingly peripheral actors and actants [74] —as well as to the manifold interrelations between the human and the "natural" world.

Actor-centered network analysis is one of the most frequently applied methods to entangle these diverse interconnections [75] (pp. 125-130). Considering the importance of local/individual actors as the actual agents and drivers of transnational networks and processes, it is surprising how little attention they have received so far in the his- 
tory of technology and environmental history of post/colonial Africa $[69,76-81]^{11}$. Most studies focus on key "Western" actors such as colonial experts, businesses, and planners, as well as on the central hubs—or "portals" [82]—of globalization (port cities in particular) [83,84], [29] (pp. 152-158). We still know relatively little about the people who made up the medium- und lower levels of these networks, and how they interacted with each other-from administrative and commercial staff such as civil and electrical engineers, plumbers and fitters, to local artisans, mechanics, and crafts-persons, (self)repairmen, or saleswomen. Which kind of "trading" or "contact zones" existed-"social spaces where cultures meet, clash, and grapple with each other, often in contexts of highly asymmetrical relations of power" [85] (p. 34) - and how were (ex)changes negotiated "on the ground" $[86-88]^{12}$. How important was mobility between social groups and regions-and how interconnected was the colonial world beyond its European and indigenous elites? Were networks of transfer "imperially" or regionally shaped (e.g., within East Africa, but across the spheres of interest of different European colonial powers)? How closely linked were Britain's African and Asian zones of influence within the British Empire? These are just some of the many questions still up for debate.

One thing is for sure, however. The central position of Western actors within colonial networks of transfer and exchange needs to be reconsidered-as objects of study as well as in terms of their respective authority and influence. The history of medicine and science has been the vanguard in this line of study, repeatedly demonstrating the importance of indigenous medical, agrarian, or technical expertise within networks of colonial knowledge, from quinine prophylaxis to channel construction [48,89-91]. Much discussed in recent years, for example, was the "Black Rice" thesis. Countering the belief that Europeans first introduced rice to West Africa and later transferred the knowledge of its cultivation to the Americas, Judith A. Carney, amongst others, has emphasized the key role of Africans-and African-American slaves in particular-in bringing the necessary seeds, cultivation skills, and cultural practices to the New World. The specific contribution of Africans to the American plantation systems (beyond their obvious role as laborers) is still controversial $[46,92]$.

What is more, humans were not the only active participants in such colonial networks of transfer. Far from being mere passive objects of exchange, artefacts, animals, plants, and microbes also possess an agency of their own, making them active parts of global interconnections $[70,93,94]$. The most prominent example of how closely the fates of humans were (and are) entwined with their fellow creatures might be the "Columbian Exchange" of species. As Alfred Crosby has pointed out in 1972 [95], the global transfer of biota not only irrevocably altered ecosystems around the world, but also shaped the process of colonialism itself, as bacteria and viruses weakened and decimated the indigenous people of the "New World" even more profoundly than European weapons did. Newly introduced crops and livestock also diversified and altered local diets and culinary habits (e.g., potatoes, maize, or tomatoes from the Americas to Europe; horses, apples, or rice from the Old to the New World). Some neophytes-whether introduced intentionally or inadvertently as stowaways-adapted to their new habitats so successfully that they turned into invasive species, harming and supplanting the indigenous biota [30,96]. But how to conceptualize such complex interrelations-between species, between society and the environment, but also between the living and the material world? Three approaches stand out: Actor-Network-Theory (ANT), the commodity-chain-approach, and the notion of a "colonial metabolism".

With its proclivity for "thick descriptions", Bruno Latour's Actor-Network-Theory [97] is particularly useful for capturing interactions between human and non-human entities within transient networks of social relations [98,99]. Building on Latour's ideas, Ronan Shamir, in his study on the electrification of Palestine in the 1920s [100], suggested looking at the "flattened" landscape of infrastructural development, giving attention not only to the activities and agency of human actors like colonial administrators, commercial companies, or private consumers, but equally to material entities and natural forces such as bodies of 
water, high voltage lines, or electricity meters. Far from functioning as mere intermediaries implementing the political agency of their creators, his study indicates that non-human actants also acted as mediators, actively-and sometime unpredictably-shaping history according to their own "intrinsic" logic [39] (p. 374). Histories of hydropower along African streams or studies on fish and agricultures also highlight the active and dynamic role of natural forces in processes of technological change $[15,19,101]$. The agency of natural conditions in post/colonial histories of technology is a topic worth pursuing in future research.

Few studies have so far attempted to explore post/colonial history of technology and the environment from an ANT perspective. More common are macro-studies examining pathways of trade, linking sites of extraction, production, and consumption across the globe. Pioneered by Sidney Mintz' seminal work "Sweetness and Power" from 1985 [102], a considerable number of transnational resource histories have traced flows of commodities and goods around the globe-from cash crops such as cotton, sugar, or tea, to manufactured articles like sewing machines, cars, or mobile phones, to "exotic" plants and animals or energy carries such as timber, kerosene/petroleum, uranium, or natural gas $[59,103-107]^{13}$. Often following a commodity chain approach [59,108-110], these works not only show the tremendous variety of individuals, institutions, and organisms involved in global networks of transfer- " from working-class consumers in London to tea pickers in Sri Lanka, from merchants and markets in New Zealand and China to indigenous hunters in North America and from birds migrating between Europe and Africa to British administers in East Africa" [70] (p. 3). They also demonstrate how different societies and their environments were deeply linked by "eco-cultural networks" [ibid] which crossed political-administrative borders of nation-states and territories in often unexpected ways $[45,48,73,111]^{14}$.

Such networks of transfer connected and affected the societies and environments of "producer" and "consumer" countries in manifold ways-most notoriously in the form of the Transatlantic "Triangular Trade" in slaves, sugar, and textiles [102]. "Energy imperialism" [112] is another case in point ${ }^{15}$. In the 19th and 20th centuries, access to abundant energy supplies, particularly to fossil fuels such as coal or petroleum, gave a boost to industrial, economic, and technological development. It was therefore highly contested as well as subject to asymmetrical power relations [113-115] ${ }^{16}$. Control over energy resources gave colonial powers such as Britain ("homeland" of the Industrial Revolution) a significant edge, fueling industries at home and reorienting trade relations to benefit the metropolis, a significant factor in the "Great Divergence" between Western and non-Western countries [116,117]. The geopolitical importance of energy carriers should increase even further in the post-WWII-period, with petroleum replacing coal, and the USA superseding Britain as the world's number one power [118-120]. With the accelerating emission of greenhouse gases, this two-fold fossil energy transition also induced global warming and inaugurated a new geological age, the Anthropocene $[121,122]^{17}$ —raising serious questions of energy justice as the countries most affected by climate change in the Global South were (and are) rarely those most responsible for excessively extracting and burning fossil fuels $[123,124]$.

Most studies tracing these networks and developments focus on specific commodities or energies. How different flows of materials, goods, resources, or energies interrelated with each other and merged within the larger metabolism of society has rarely been explored in full. In his classic analysis "Nature's Metropolis" [125], William Cronon has traced the many intimate linkages between city and country, society and the environment, showing how the city of Chicago functioned as a giant magnet for rural resources and urban commodities, restructuring and organizing the environments of its ever-expanding hinterlands to satisfy its needs. Not only hunger for resources and raw materials contributed to such a colonization of nature, however, but also the myriad outputs of (industrial) society, particularly its refuse and waste. Environmental history has examined the urban metabolism through an analysis of material and energy flows [126-129] ${ }^{18}$. With few exceptions such as Hongkong [130], however, this approach has rarely been applied to colonial 
contexts [131,132]. The task is a demanding one, as not only city-hinterland relations with their in- and output flows of energies, substances, or commodities need to be taken into consideration, but also exchanges between colonies and/or the European metropolis. This requires a complex set of data that is not easily available for non-Western or pre-modern societies. Conceptualizing colonial cities and societies as organisms that metabolize-and colonize-nature also bears a certain risk of simplifying colonial social and power relations, as both colonizers and colonized, rich and poor, are subsumed within one-sometimes symbiotic, sometimes dysfunctional-body of community. If carefully contextualized, such a quantitative (but also qualitative) analysis of the material dimension of colonialism might, however, also allow fresh insights into the complexities of colonial human-environment interrelations: (how) did material flows change between colonial, postcolonial, and precolonial times? Which cities and social groups competed with each other for supply of important resources? Who enjoyed privileges? How was disposal or recovery of refuse and waste organized-and how did city planners, engineers, and citizens envision the myriad materials and energies that circulated through and sustained their living spaces ([133] on circular thinking in concepts of urban hygiene)? There is still much to be learned on the workings of what might be called the "colonial metabolism" — both for specific colonial spaces and colonial societies in general.

\section{Rethinking (Colonial) Infrastructures and the Concept of "Large Technical Systems"}

In post/colonial histories of technology and the environment, infrastructures are often conceptualized as first-rate instruments of power. In these narratives, steamships and railways, telegraphs and telephones, and most recently the internet, not only function(ed) as central drivers of imperialism and (later) globalization [134] [(pp. 1012-1029)], [135]. Often introduced and/or expanded as part of the colonial project, infrastructures such as sewage and water supply systems continued to shape the trajectories of urban development until long after independence, perpetuating inequalities well into the future by "storing" existing power structures and imbalances [136-138]. A colonial legacy sometimes literally turned to and carved into stone, these structures made it difficult to implement utilities more appropriate to the financial, social, topographical, ecological, or demographic situations on site [139].

Despite their apparent prominence in colonial history, there is still much we do not know about how infrastructures affected life in Europe's oversea territories. For subSaharan Africa, even the "big three" — steam ships, railways, and the telegraph-have only been selectively explored [26,140-147] ${ }^{19}$. Research on road, energy, or electricity infrastructures had been a particular lacuna which has recently been tackled more systematically in post/colonial history of technology and the environment ([148-155] on roads and transport; [15,19,20,156-159] on energy and electricity). Most studies focus on urban infrastructures, exploring how water supply or sanitation systems contributed to-or undermined - the creation of colonial spaces in line with the "dual city" model of segregated urban planning [18,29,160-166]. How different kinds of infrastructures related to each other as interconnected parts of the "networked city" has rarely been investigated. It is still up for debate whether this central idea of Western urban planning is even pertinent in post/colonial contexts [79,167-170].

The "networked city" is only one of many supposedly universal concepts from (Western) Science and Technology Studies (STS) that we need to rethink critically when investigating infrastructures in the Global South. In this section, I will take a closer look at Thomas P. Hughes widely influential notion of "Large (Socio)Technical Systems" (LTS) [171,172], unpacking its implications for post/colonial STS. In accordance to Clapperton Chakanetsa Mavhunga's reasoning that an STS perspective is severely limited in non-Western contexts [173] (p. XI), [174], I am arguing that, despite its merits as an analytical tool, expectations of Western "standard" developments are so deeply entwined with this seemingly universal model that they restrict rather than inspire us in the narratives we might tell. Shedding preconceived notions of how infrastructures should be organized (namely as 
centralized systems of supply), we need other analytical tools to disentangle the complicated mélange of formal and informal arrangements that often characterizes life in the Global South $[58]^{20}$. Recent STS works have proposed fresh approaches for infrastructure studies, including notions of "inverse" or "pirate" infrastructures (Larkin), or AbdouMaliq Simone's suggestion of conceptualizing people as infrastructures. I will discuss these approaches in the second part of this section.

LTS aims to explain the emergence, functioning, and persistence of infrastructures within an overarching model of technological development. Analyzing the electrification of Germany, Great Britain, and the USA between 1880 and 1930, Hughes identified four phases of system development, each of which characterized and shaped by a distinct set of "system builders": innovation and development; technology transfer; system growth; and consolidation. Particularly persuasive was the idea of "momentum". As technical systems grow in size and stabilize, their ability to meet new challenges with flexibility diminishes. Path developments are now determined and shaped by the most cumbersome system components ("reverse salient"). Noticing significant variations in how these general patterns played out in his specific case studies, Hughes also highlighted the co-dependency of technological systems with their social environment. Each system exhibits its own characteristics, which accrue to distinct, yet comparable "national styles". Emphasizing the "social construction of technologies", the LTS approach was thus apparently adaptable to a variety of context and cultures [175] (pp. 90-93].

[The LTS approach has been widely applied, criticized, and refined since the 1980s [176] (pp. 10-11)]. For example, the central position of "system builders" as key drivers of technological change has been questioned repeatedly, as this essentially boils down to a "great men make history" notion of development [177] [(pp. 1434-1436)], [178]. Environmental factors, which played only a minor role in Hughes' original concept, were also given more consideration. Moving beyond the natural resources necessary for production of electricity or artefacts, researchers over time also scrutinized the co-dependence of technological systems with their natural environments, and investigated questions of (un)sustainability and socioecological inequality $[176,179]$ (pp. 543-544). In the process, environmental features were increasingly regarded as dynamic and active, rather than as static and passive elements of socio-technical systems-and as crucial parameters for the vulnerability or resilience of infrastructures and societies.

While the LTS approach has rarely been utilized directly for analyzing technological change in non-Western societies [139,180], many interpretations of networked infrastructures in the Global South at least implicitly measure their paths of development against the permanence and solidity, the spatial expansion and technical efficiency of their Western counterparts. How might we then conceptualize a (global) history of infrastructures that accounts for possible differences in developments without the Western model as the central point of reference, stigmatizing variations as deviations in an inadvertent process of "othering"? Is it even possible to productively translate STS theories and concepts devised for and within Western technological contexts to other world regions, as Hughes himself had hoped in his introduction to "Networks of Power" [171] (p. 7) ${ }^{21}$, without falling into the normative trap of "universal" approaches-or do we, by questioning the notion of universality, risk an even more profound "othering" of societies of the Global South?

There are no easy answers to these questions. On the one hand, LTS-as a general model of analysis-might very well be utilized as a tool for generating questions on infrastructural developments in the Global South from a systemic point of view: can we identify similar and/or distinct post/colonial variants of technological change, or "technological styles" specific to the Global South? Who or what were key drivers or "system builders"? Did colonization and decolonization cause ruptures in infrastructural developments, and which additional factors contributed to the success or decline of (pre)colonial infrastructures, e.g., topography, climate/weather conditions, or social hierarchies? By exposing Western models of development to scrutiny and global comparison, such analytical frameworks allow us to question LTS as a universal model, and revisit its central premises. As 
a matter of fact, recent research suggests that system development in the Global South was multifactored and rarely adhered to "universal" expectations $[19,139]$. The growth phase of system development, for example, was apparently more subdued in post/colonial contexts. Underestimating indigenous people as potential customers, economies of scale often failed to materialize before momentum set in.

While applying LTS to the Global South might thus result in valuable gains of knowledge, expectations of Western "standard" developments also limits us in the narratives we can tell. From an LTS point of view, the history of infrastructures in the Global South is a history of arrested developments, fragmentation, and decay. Many studies on post/colonial Africa hence present a picture of "failing", "crumbling", or "dysfunctional" infrastructures [162,181,182]. Disruptions in urban sewage and water supply systems in particular are frequently interpreted as examples of "splintering urbanism" [183]. Caught up in our expectations of which utilities are to be regarded as essential and how infrastructures should be organized to foster (urban) life, we often fail to question whether centralized systems of supply are actually the most feasible or efficient solutions given the socio-cultural, ecological, topographical, and, last but not least, financial conditions on site [169].

Not being serviced by central infrastructures, the inhabitants of informal settlements such as Nairobi's Kibera area, for example, have devised alternative ways for securing basic amenities such as water, electricity, sanitation, or postal services. Consumers might acquire fresh or brown water either via a system of water-kiosks, through push-cart vendors, or by accessing standpipes located at the fringes of neighborhoods. Fixed-point water vending has a long history in Nairobi, as Jethron Ayumbah Akallah has pointed out, dating back to the 1940s, as does the decentralized collection of night-soil, later to be dumped either into rivers or at official waste sites. Both cases show "independent, distributed systems working seamlessly with centralized networks to attain a working equilibrium" [184].

Everyday life in the Global South was and is thus often characterized by a complicated mélange of formal and informal arrangements [185-188]. Sometimes informal systems substitute or supplement formal ones as "back-up systems" (e.g., private generators that kick in in case of electricity failure) [189]. Sometimes gaining access to formal networks at all is mediated by or dependent on informal arrangements, for example, illegal connections to public water or electricity networks. In Africa's expanding mega-cities, for instance, informal settlements are seldom officially connected to grids, as this would give squatters' citizens' rights $[184,190]$. Privatization of state or municipal utilities, demanded by international donors (especially the World Bank) since the mid-1980s as a prerequisite for further funding, also acerbated problems of access, leading to a deliberate reduction in the number of clients as consumers who were unable or unwilling to pay were disconnected from services [157] (pp. 19-20). In these circumstances, tapping of wires or shared access points were and still are sometimes the only way for the urban poor to gain at least some access to basic services. When South Africa introduced prepaid meters in poorer quarters in the late 1980s, for example, this resulted in a tenacious struggle between utilities and consumers to enhance or outsmart meters [191]. In order to reduce "electricity theft", Kenya Power has thus recently introduced a community-based approach in Nairobi's Kibera area, reducing tariffs as well as integrating informal suppliers of electricity into the formal electricity system. Previously occupied with "hooking" residents to wires or illegally modifying meters, these vendors now function as mediators between the utility and its (potential) clients, selling pre-paid Kenya Power chits as part of its new pay-as-you-go scheme [192] The example of Kenya Power demonstrates how so-called "pirate infrastructures" not only constitute spatial and social networks of their own, but are sometimes "so thoroughly intertwined [with legal ones] that it is hard to separate one from the other" [193] (p. 83). In addition, such arrangements and networks are often transient [194], with "old", "new", and "hybrid" technologies, services, and practices coexisting and intertwined. These complex arrangements resist attempts of being pressed into a rigid scheme of "large technical systems" [195,196]. 
History of technology and STS studies thus need to be more grounded into the realities of life-for the Global South, but also for the Global North [39,43,194,197-199]. A couple of promising approaches are on the table. In a symmetric inversion of ANT notions of including non-human actants into the analysis of social networks, cultural theorist and anthropologist AbdouMaliq Simone has in turn suggested a similar but reverse perspective for studying infrastructures, perceiving not only the technical components of the system, such as pipes or cables, but also humans and their actions as infrastructures [200]. In this view, it is precisely the unpredictability and diversity of human (inter)actions that builds the backbone of (African) city life, "depending on the ability of residents to engage complex combinations of objects, space, persons, and practices. These conjunctions become an infrastructure-a platform providing for and reproducing life in the city" [ibid] (pp. 407-408). As Alex Taylor has pointed out in his reflections on Simone's paper, engaging with the provisional, collaborative practices of Johannesburg's residents-even, or rather: especially if they operate at the fringes of mainstream society-thus "opens up a manifestly different set of (infra)structures and practices that force a reimaging of how cities might be organized" [201]. In turn, the concept of "people as infrastructures" also raises questions of civil accountability and the mechanisms of social control. In this regard, people are not only an "infrastructure of relationships, they also form infrastructures of surveillance" [ibid] (anonymous comment, 7.12.2013).

Another concept challenging top-down models of centralized infrastructural development is the notion of "inverse infrastructures" [202] — networks and services that originated through the engagement of small-scale local initiatives and the agency of their users. Exploring the circumstances that allowed some of these "infrastructures from below" to flourish while others remained marginal, or were suppressed and/or absorbed by the mainstream systems, seems especially relevant for the Global South where decentralized approaches (e.g., solar energy micro grids) are currently discussed as possible low-cost alternatives to large-scale structures.

In addition, last but not least, research might also pick up on the double notion of "infrastructure as environment" resp. "nature as infrastructure" [179,203] and explore this juxtaposition for post/colonial societies and contexts. Infrastructures not only depended on natural resources and shaped landscapes and environments, turning, for example, rivers into energy sources and navigable waterways [19]. They also constituted artificial environments themselves (e.g., artificial light, regulated indoor temperatures, easy access to fresh water), transforming - at least in theory-nature into a consumable good and "othering" "wild", uncontrolled nature (also with regard to human bodies) as the opposite of society and technology [203] (pp. 188-189). Critical analysis, as well as time, has revealed this modernist quest for control as wishful thinking, and highlighted its oftendisastrous consequences [15,29,90,204,205]. While climate change has pushed questions of vulnerability and resilience to the forefront of current policy debates on natural hazards, risk management and critical infrastructures both for the Global South and North [206-209], these discussions often lack a historical dimension, scrutinizing, for example, legacies of colonialism for present (infrastructural) vulnerabilities, or exploring historical coping strategies and culture of resilience ${ }^{22}$.

Emphasizing such tensions, but also the entanglements between small- and large-scale systems, formal and informal arrangements, nature and society, or the agency of its human and non-human users, these approaches might not only help us to regard the history of post/colonial infrastructures in a more context-sensitive light, but also provide valuable impulses for a more differentiated view of infrastructural developments in the Western hemisphere as well.

\section{Post/Colonial Microhistories-Discourses, Identities, and Everyday Practices}

Microhistories accentuating technological practices and perceptions have been frequently lauded as the most promising path in (global) history of technology in order to balance and counter the persistent narrative of technological globalization as an encompassing 
top-down process $[43,87,197,210]$. Despite frequent calls to investigate "technologies-inuse", the state of the art is still rather fragmented, however. In this section, I will give a brief overview on the heterogenous body of research investigating everyday practices and technical imageries in the Global South. I am arguing that despite their prominence in conceptual articles and position papers, there is still much to be learned about how (and which) technologies shaped everyday life in the post/colonial world (and vice versa), especially regarding the interrelations between environmental and technical practices and perceptions. For this, we need to move beyond the familiar "key technologies" depicted in Western histories of technological change, and scrutinize place- and time-specific landscapes of technology instead, regardless of labels such as Western or non-Western, "modern", "traditional", or "hybrid". We also need to take a closer look at what actually constituted the much-invoked "African agency" ([211] on the concept of agency) for specific actors and groups-and pay close attention to the intersectionality of social categories such as race, class, ethnicity, religion, age, education, or gender.

How technologies contributed to the construction of social identities in colonial contexts (or were instrumentalized this way) has been a particular focus of scholarly attention since Michael Adas famous “Machines as the Measure of Men” [27] (see also [159,212-216]). Research on the techno-politics of colonialism has shown that technological imageries played a vital role in group and nation building processes as well as in the "othering" of outgroups [217-219]. Equaling moral decay and physical filth, for example, the Gold Coast newspaper "Daily Graphic" explicitly framed its calls for hygienic bodily practices and improved sanitation in 1950s Accra in a language of citizenship and civic responsibility. In these narratives, becoming a citizen was a transformative process, "a conscious act of awakening that required individual men and women to align their regular tasks with national needs, values, and ideals [ ... ] [including] a fervent respect for infrastructural modernity" [220] (p. 154). In this vein, adopting specific technological practices or artefacts turned into patriotic acts and signs of belonging - to the nation state, but also to wider notions of modernity (resp. tradition, in case of rejection) $[221-223]^{23}$. Many newly (or soon-to-be) independent nations in Africa and Asia in the 1940s and 1950s were deeply committed to the idea of technical modernity. Prestige projects such as Ghana's Akosombo Dam on the Volta River were ideologically supercharged as symbols of state power, signifying technological competence and control over the environment as well as transporting claims of equality within the community of nations [224]. Technologies and artefacts not only contributed to the construction of national identities, but were also vehicles of individual self-expression, indicating specific group affiliations and lifestyles preferences (e.g., [225] on fashion and body politics in imperial Sudan)—albeit choices of technologies and artefacts also depended on externalities such as availability or affordability [226]. In contrast to the extensive discussions on the political symbolisms of technologies, research on these more intimate technical imageries is still in its infancy with regard to post/colonial Africa ${ }^{24}$.

There is growing interest in the specifics and changes of Africa's diverse material cultures, however, both from history of consumption [227-231] and history of technology. Inspired by David Edgerton's seminal book on "The Shock of the Old" from 2007 [197] as well as David Arnolds pioneering transfer studies on "Everyday Technologies" in British India [43], research has particularly focused on the interrelations of "traditional" and "modern" technologies, practices, and bodies of knowledge. Edgerton's work has been especially fruitful, highlighting new avenues of study as well as giving tantalizing glimpses into possible empirical materials. Criticizing history of technology's narrow fixation on technical innovations, Edgerton suggested a significant broadening of scope: histories of technology should investigate the whole life cycle of technologies, from cradle to grave, including processes of maintenance and repair $[153,232,233]^{25}$, with a special emphasis on "technologies-in-use" [51,234].

As Edgerton himself emphasized, this shift in perspective is particularly pressing with regard to the Global South [197]. Here, traditional techniques not only continued to shape daily life for much longer than in the Global North. Established technologies were 
also reconfigured and adapted to meet local needs [43,193], and merged into hybrids, or "creole technologies" [235], for instance, the much-cited cycle rickshaw [197] (pp. 45-47). Sometimes, specific "technologies of the poor" emerged (e.g., the famous Kenyan "flying toilet" [235] (pp. 92-100, in particular 96) which have no equivalent in the rich countries of the West. Moreover, the importance of technologies varied between rich and poor countries. Corrugated iron, used for making tin roofs, was infinitely more widespread and beneficial for daily life in the Global South than, for example, television sets or refrigerators-technologies frequently regarded as key indicators of social change in the Global North (see also [236] on the importance of concrete for housing practices and policies). Mapping the whole technological landscape of post/colonial societies beyond the familiar "key technologies" of industrial modernity - but also regardless of labels such as Western or non-Western, "modern", "traditional", or "hybrid" - and tracing their persistence and change over time might guide us to a better understanding of how technologies and infrastructures worked within specific parameters of time, place, and culture.

Not only Africans' technological practices and perceptions, but also their interrelations with nature and the environment have so far been primarily regarded through an "imperial" lens. Most environmental histories focusing on the colonial period are concerned with the activities of the European colonizers, on resource extraction, cash crops, and plantations, as well as on tensions between the exploitation and subjugation of nature (e.g., dam building, irrigation, hunting) and colonial conservation efforts [9,29,30,33,237-241]. In these narratives, the activities and agencies of local people often take a backseat. In parallel to this strand of research, there is a significant number of studies that explore indigenous environmental knowledge and practices, questions of environmental justice or the "environmentalism of the poor", often from a postcolonial/subaltern perspective [242-246]. Despite continued interest in African resource management and land use practices [10,38,247-250], there is still much to be learned about how non-Europeans engaged in environmental modifications over time in sometimes sustainable, sometime destructive ways, and how changing technological and environmental practices accompanied, interfered with, and supported each other-not only in the countryside (the major focus of African environmental history), but also in urban and peri-urban settings [251,252].

Whether "big" infrastructures or "small" artefacts, intimate natural spaces or the environment in general, everyday histories of technology and the environment in post/colonial Africa offer plenty of material for further investigations: which technologies, goods, or services were available and (how) did "foreign" (but also local) innovations interact with traditional technologies and practices? To what extend did local geographies, climate and weather conditions, or river flows affect sociotechnical processes, or influence promoted local technological solutions and practices? How were these technologies and environments perceived and framed? How did the agency of different groups-including non-human actants and natural conditions-manifest in these discourses and practices? Or, in Clapperton Chakanetsa Mavhunga's words: "What [were] Africans doing to, with, and through these things [technologies and artefacts]" [174] (p. 27)? Who had access to (which) technologies and environmental goods, to which purposes, and how did this change over time? In addition, last but not least, how did social categories such as race, ethnicity, class, religion, education, age, or gender [253] come into play and intersect?

For sub-Saharan Africa, from these cross-sectional social categories, racially motivated exclusion has been the most frequently and best-explored [29] (pp. 167-183), [167]. In his study on colonial Bulawayo in Southern Rhodesia, for example, Mhoze Chikowero has shown how private access to electricity had been deliberately discouraged in black quarters through restrictive grid design, limited supply, and higher tariffs [156]. Other (urban) technologies and infrastructures forged similar geographies of inequality-the often-cited "cordon sanitaire" between European and indigenous quarters being the most infamous [166]. This notion of colonial cities as "dual cities", characterized by a sharp segregation of "black" and "white" urban spaces and practices, has been complicated by recent studies [254-257]. In many cases, the "dual city" seems to have been more of 
an administrative and urban planning ideal than actual reality. "The colonial ordering of urban space was incomplete as the colonial powers lacked the resources to enforce segregation ordinances while many Africans circumvented colonial regulations even in the stricter eastern and southern African colonial regimes" [50] (pp. 229-230). The same holds true for many supposed "Tools of Empire" such as railways, steamships, or the telegraph. Despite their intent as instruments of power, their actual usages and effects were often ambiguous, as even Headrick himself has accentuated. At times exhibiting a strong segregating power, for example, by restricting access to European users, they were also claimed and appropriated by the local people $[18,43,141,146,159,258,259]$.

Far from being mere objects of colonial rule, Africans thus displayed considerable agency in shaping urban spaces and landscapes. As Adewumi Damilola Adebayo has demonstrated in his unpublished presentation at the 2019 SHOT Conference in Milan, African taxpayers in colonial Lagos successfully utilized colonial attempts to introduce municipal taxes (e.g., for urban lighting) for asserting greater African representation in matters of local administration [260]. In many African countries, access to urban technologies and services was a contested battlefield, a tug-of-war between colonial exclusivity and control versus local participation and autonomy [12,100,159]—an autonomy that could manifest itself both in the appropriation or rejection of technological practices and artefacts. Similarly, access to and usage of natural resources (particularly land) also remained controversial, with local African communities repeatedly having to circumvent colonial efforts of controlling and taking over their ancestral lands by introducing "scientific" land-use practices or designating nature reserves with restricted access rights [261]. Experiences thus greatly varied over space and time, and were shaped by a multitude of factors of which race/ethnicity was one of many parameters [50,63,213].

\section{Conclusions}

In many ways, writing histories of technology and the environment of (and in) the Global South resembles a patchwork quilt-with a lot of collaborative weaving yet to be done. Some parts of the tapestry already shine in multi-layered glory, while others are mere blanks still to be filled in. There are few well-trodden sections. Of course, the project is not without its snares: which motifs should we insert into the tableau? How can we connect the multi-colored empirical details with the topic's larger patterns and structures? Who shall—and might-participate in the weaving? And-in view of the overabundance of fabric and material-should we not disband the idea of one room-fitting enviro-technical tapestry of the Global South altogether, and instead create many small runners and rugs [24] (p. 180, own translation)? There are certainly many threads to follow:

Histories of globalization? Tracing the spread, (ex)change and appropriation of technologies and infrastructures around the globe is certainly the most frequent, but arguably also the most conventional way of writing post/colonial histories of technologies. The possible pitfalls of this approach are well-known. Following the paths of key Western technologies, actors, or expertise is not only inherently Eurocentric, it also comes at the expense of actors, technologies, or regions that "fall through the cracks" as they were never part of - or deliberately excluded from—networks of global exchange (see $[52,65]$ on global disconnections). In order to get at the heart of how people utilized technologies in different contexts and times, we need to move beyond straightforward histories of technological globalization. One way of doing so might be to survey the technological landscapes of specific social groups or regions (ideally in connection with their natural environments), another one to investigate which solutions people developed to meet similar (technological) challenges (e.g., for irrigation or cooling) [262]. Mapping different "cultures of technology" and tracing their persistence and change over time might guide us to a better understanding of how technologies and infrastructures worked within specific parameters of time, place, and culture. Such research designs (can) work outside the logic of the globalization narrative as they do not innately depend on the existence or increase of transnational-global connections [ibid]. So far, however, most of this research is still done in comparison to West- 
ern pathways, for example, as part of the debate on the "Great Divergence" [117,263,264], and is therefore also subject to the teleology of Western "standard" narratives ([262] for a critical discussion).

So, no more histories of technological globalization? That might be throwing out the baby with the bath water. Particularly with regard to post/colonial Africa, there is still much to be learned about how-and which-technologies and infrastructures were developed and utilized over time, which stakeholders were involved in these processes and how this changed technological practices and perceptions. As a matter of fact, the concrete processes and mechanisms of "doing global" [265] are still surprisingly little explored in both history of technology and environmental history. Focusing on the many ambivalences of "global" technological (ex)changes, histories of supposedly "global" technologies and infrastructures might thus play their own part in deconstructing classic narratives of global modernization and interconnectedness.

Meta narratives or microhistories? In order to achieve this goal, writing microhistories has been lauded in recent years as the most promising path off the beaten tracks of eurocentrism and the globalization narrative $[266-268]^{26}$. There is much to be said for this approach. Global history has a tendency for abstraction and generalization, crystallizing complex and sometimes contradictory developments into supposedly universal processes [98] (pp. 22-24). Within these meta narratives, the agency of individual actors and actants - if they do not qualify as "key players" - is often lost or reduced to anecdotal evidence. Microhistories that exemplify the richness and variety of historical experiences "on the ground" offer valuable counter-narratives and reality checks to these meta narratives [269]. In post/colonial history of technology, David Edgerton's and David Arnold's suggestions to explore "technologies in use" resp. "everyday technologies" have been particularly fruitful [22,43]. More work still needs to be done, however, to situate the manifold fragmented glimpses into the past in relation to each other, to compare and connect the dots as well as bridge the widening gap between those studies that focus on "big structures" and those that highlight individual experiences and "agency" [270] 27 .

So, what can be done? As with most "global" history projects, writing post/colonial histories of technology and the environment is an equally alluring and challenging task-and one best approached as a joint endeavor [24] (pp. 180-182). For this project to be successful, it will require a plurality of visions, perspectives, and methods. We need ambitious meta narratives as well as a diversity of regional microhistories; analyses of large global infrastructures as well as studies of small, everyday technologies-and the outside view of Westerly socialized historians as well as insights from non-Western academia. Above all, we need studies that tackle and resolve traditional boundaries-in our conceptual thinking, but also between historical disciplines. Writing global or post/colonial histories of technology and the environment is an invitation to play with different scales and perspectives, a chance for bricolage and experiments. Both history of technology and environmental history need global, post/colonial perspectives-and vice versa, as an extension of their traditional regional and thematic foci, but also as an incentive to revisit central concepts and assumptions. If we manage to walk the line between the double conceptual chasms of "universality" and "particularism" [52,271,272], post/colonial histories of technology and the environment offer the opportunity of gaining fresh insights, not only into their specific fields of study, but also regarding some of the core questions of our disciplines: how did technologies and the environment shape human life (and vice versa) - and how did those experiences compare for different social groups and societies?

Funding: This research received no external funding.

Institutional Review Board Statement: Not applicable.

Informed Consent Statement: Not applicable.

Data Availability Statement: Not applicable. 


\begin{abstract}
Acknowledgments: This article builds on two previously published review articles [24,39] and offers a careful revision and extension of their argumentation. It is linked to my ongoing research project "Empires of Light, Empires of Darkness: Technology, Politics and Culture in Colonial History" on the history of lighting in the British Empire. I would like to thank the Rachel Carson Center for Environment and Society (RCC) in Munich for their generous financial and intellectual support that allowed me, during my LMU-fellowship, the time and resources for writing this article. I am especially grateful for the discussants of the RCC "Works in Progress" group for commenting on earlier versions of this paper. I would also like to thank my former co-author for "Connecting the Empire", Jonas van der Straeten, as well as the editors of the volume "Provokationen der Technikgeschichte", Martina Heßler and Heike Weber, for their insights on those earlier articles.
\end{abstract}

Conflicts of Interest: The author declares no conflict of interest.

\title{
Notes
}

1 For history of technology resp. Science and Technology Studies in Africa, two recent publications stand out: the volume "What Do Science, Technology, and Innovation Mean from Africa?", edited by Clapperton Chakanetsa Mavhunga, and the Technology and Culture special issue on "Africanizing the History of Technology", edited by Laura Ann Twagira [4]. Both works focus on Africa as a place of technological innovation, creativity, and adaption, emphasizing the importance of African specialists in the development of technological expertise and knowledge.

2 This timeframe is not meant to implicate that Africans-or people of the South-did not possess substantial cultures of technology before the advent of Euopean colonialism, but rather represents a practical decision of grappling with the substantive body of literature on this topic in accordance to my own areas of expertise.

3 For a bibliography, visit: https:/ / www.envirotechhistory.org/envirotech-resources/bibliography/ (accessed on 27 July 2021).

$4 \quad$ For an overview, see [9].

$5 \quad$ For a critical discussion, see [38].

6 For a bibliography of classic critiques of eurocentrism, see: https://web.archive.org/web/20160327204903/https://infinityfoundation.com/ mandala/ (accessed on 27 March 2021).

7 Most notable Joseph Needham's monumental series "Science and Civilisation in China" (SCC). Initiated in 1954, the series currently consists of 27 books (in seven volumes). SCC has repeatedly been praised as the first to emphasize Chinese scientific contributions to global knowledge, particularly for the time period prior to the 16th century.

8 See [54] (pp. 188-193) on the problem of intermediary representation.

9 See, e.g., the works of social historians Richard Roberts, Jean Allman, or Kristin Mann.

10 For a critical discussion, see [21,68].

11 A couple of pioneer studies stand out: in their comprehensive study on "Global Electrification", William J. Hausman, Peter Hertner and Mira Wilkins have traced the business activities of multinational electricity companies across the globe [77]; examining the distribution networks of Solingen cutlery, Angelika Epple has shown how stakeholders from the German "hinterland" were embedded in global systems of colonialism [76]; Casper Andersen, Joseph Morgan Hodge, Robert K. Home or David Sunderland, amongst others, have scrutinized the activities of experts and (urban) planners in Europe's African colonies, for example the British Crown Agents [69,78,79,81]. On Galison's related concept of "trading zones" [86], where people of different cultural backgrounds interact, see [87]; on concepts of place, space, and encounter in general, see [88]. For an introduction to the field, see [106]; on the concept of "commodity histories", see [107]; for case studies and resources, visit https: / www.commodityhistories.org/ (accessed on 27 July 2021). This growing body of literature on transregional and interimperial networks clearly indicate that colonial exchanges did not automatically take the route via the colonial metropolises. See special issue 3 (2020) of the Journal of Energy History on "Energy Imperialism? Resources, Power, and Environment (19th-20th cent.)".

16 See [114] for an overview.

17 On energy transitions, see [121]; on the Anthropocene, see [122].

18 See also: https:/ / metabolismofcities.org/ (accessed on 27 July 2021).

19 Post/colonial railway history has attracted significant attention in recent years, but most of this research focuses on India; for post/colonial Africa, see [148-150), see also HoST issue 12/1 (2018).

20 Akallah and Hård similarly urge historians of technology to investigate the "world beyond the network" [58] (p. 897), which is often treated as a marginal area in STS studies.

21 "It is hoped, therefore, that this history of a particular kind of system will be of some assistance to other historians who wish to study other systems." 
Based on oral history interviews in Nairobi (Kenya), Jethron Ayumbah Akallah and Mikael Hård argue in [58] that inhabitats of informal settlements not served by the centralised water network exhibited a higher degree of resilience than those with access to such services. After the introduction of piped water, residents actually became more vulnerable to water shortages than they had previously been. See also [89] on the hydro-resilience of pre/colonial landscapes and people.

23 This body of literature particularly highlights the ambivalent reactions to technical modernity and urban life in the Global South. For a critical view, see also [52].

24 For a study combining both aspects, see [146], which scrutinizes both the political symbolism of railway construction as well as how these processes influenced local identities and sense of belonging.

25 There is very little historical research on maintenance and repair in the Global South, particularly for the colonial period. See [232] on the Public Works Department in Dar es Salaam; [153] on cultures of improvisation in Ghana's automobile sector; and [233] on the "dark side" of repair.

26 See also Issue Supplement 14 on "Global History and Microhistory" of the journal "Past \& Present" from 2019.

In [270], de Vries highlights the challenges of combining different scales, questioning the idea of "zooming" from macro to micro scales.

\section{References}

1. Chakrabarty, D. Provincializing Europe: Postcolonial Thought and Historical Difference; Oxford University Press: New Delhi, India, 2000.

2. Komlosy, A. Globalgeschichte: Methoden und Theorien; Böhlau: Vienna, Austria, 2011.

3. Sachsenmaier, D. Global History, Version 1.0. Docupedia-Zeitgeschichte. 11 February 2010. Available online: https://zeitgeschichtedigital.de/doks/frontdoor/index/index/docId/588 (accessed on 27 February 2021).

4. Twagira, L.A. Africanizing the History of Technology. Technol. Cult. 2020, 61 (Suppl. S2), 1-19. [CrossRef]

5. Jørgensen, D.; Jørgensen, F.A.; Pritchard, S.B. (Eds.) New Natures: Joining Environmental History with Science and Technology Studies; University of Pittsburgh Press: Pittsburgh, PA, USA, 2013.

6. Pritchard, S.B.; Zimring, C.A. Technology and the Environment in History; Johns Hopkins University Press: Baltimore, MD, USA, 2020.

7. Reuss, M.; Cutcliffe, S.H. (Eds.) The Illusory Boundary: Environment and Technology in History; University of Virginia Press: Charlottesville, VA, USA, 2010.

8. Russell, E.; Allison, J.; Finger, T.; Brown, J.K.; Balogh, B.; Carlson, W.B. The Nature of Power: Synthesizing the History of Technology and Environmental History. Technol. Cult. 2011, 52, 246-259. [CrossRef] [PubMed]

9. Beattie, J. Recent Themes in the Environmental History of the British Empire. Hist. Compass 2012, 10, 129-139. [CrossRef]

10. Bender, M.V. Water Brings No Harm: Management Knowledge and the Struggle for the Waters of Kilimanjaro; Ohio University Press: Athens, OH, USA, 2019.

11. Brownell, E. Gone to Ground: A History of Environment and Infrastructure in Dar es Salaam; University of Pittsburg Press: Pittsburg, PA, USA, 2020.

12. Falola, T.; Brownell, E. (Eds.) Landscape, Environment, and Technology in Colonial and Postcolonial Africa; Routledge: New York, NY, USA; London, UK, 2012.

13. Gandy, M. The Fabric of Space: Water, Modernity, and the Urban Imagination; MIT Press: Cambridge, MA, USA, 2014.

14. Headrick, D.R. Power over Peoples: Technology, Environments, and Western Imperialism, 1400 to the Present; Princeton University Press: Princeton, NJ, USA, 2010.

15. Hoag, H.J. Developing the Rivers of East and West Africa: An Environmental History; Bloomsbury: London, UK, 2013.

16. Isaacman, A.F.; Issacman, B.S. Dams, Displacement, and the Delusion of Development: Cahora Bassa and its Legacies in Mozambique, 1965-2007; Ohio University Press: Athens, OH, USA, 2013.

17. Miescher, S.F. A Dam for Africa: Akosombo Stories from Ghana; Indiana University Press: Bloomington, IN, USA, 2022.

18. Rijke-Epstein, T. The Politics of Filth: Sanitation, Work, and Competing Moralities in Urban Madagascar 1890s-1977s. J. Afr. History 2019, 60, 229-256. [CrossRef]

19. Showers, K.B. Electrifying Africa: An Environmental History with Policy Implications. Geografiska Annaler. Ser. B 2011, 93, 193-221. [CrossRef]

20. Tischler, J. Light and Power for a Multiracial Nation: The Kariba Dam Scheme in the Central African Federation; Palgrave Macmillan: Basingstoke, UK; New York, NY, USA, 2013.

21. Arnold, D. Europe, Technology, and Colonialism in the 20th Century. Hist. Technol. 2005, 21, 85-106. [CrossRef]

22. Edgerton, D. Innovation, Technology, or History: What is the Historiography of Technology about? Technol. Cult. 2010, 51, 680-697. [CrossRef]

23. Hård, M.; Jamison, A. Hubris and Hybrids: A Cultural History of Technology and Science; Routledge: New York, NY, USA, 2005.

24. Hasenöhrl, U. Globalgeschichten der Technik. In Provokationen der Technikgeschichte: Zum Reflexionszwang historischer Forschung; Heßler, M., Weber, H., Eds.; Verlag Ferdinand Schöningh: Paderborn, Germany, 2019; pp. 151-192.

25. Heßler, M.; Weber, H. (Eds.) Provokationen der Technikgeschichte: Zum Reflexionszwang historischer Forschung; Verlag Ferdinand Schöningh: Paderborn, Germany, 2019.

26. Headrick, D.R. The Tools of Empire: Technology and European Imperialism in the Nineteenth Century; Oxford University Press: New York, NY, USA, 1981. 
27. Adas, M. Machines as the Measure of Men: Science, Technology, and Ideologies of Western Dominance; Cornell University Press: Ithaca, NY, USA, 1989.

28. Fischer-Tiné, H.; Mann, M. Colonialism as Civilizing Mission: Cultural Ideology in British India; Anthem Press: London, UK, 2004.

29. Beinart, W.; Hughes, L. Environment and Empire; Oxford University Press: Oxford, UK, 2007.

30. Crosby, A.W. Ecological Imperialism: The Biological Expansion of Europe, 900-1900; Cambridge University Press: Cambridge, UK, 2004.

31. Gissibl, B. The Nature of German Imperialism: Conservation and the Politics of Wildlife in Colonial East Africa; Berghahn: New York, NY, USA; Oxford, UK, 2016.

32. Grove, R. Ecology, Climate, and Empire: Colonialism and Global Environmental History, 1400-1940; White Horse Press: Cambridge, UK, 1997.

33. Grove, R. Green Imperialism: Colonial Expansion, Tropical Island Edens and the Origins of Environmentalism, 1600-1860; Cambridge University Press: Cambridge, UK, 1995.

34. Ross, C. Ecology and Power in the Age of Empire: Europe and the Transformation of the Tropical World; Oxford University Press: Oxford, UK, 2017.

35. Gadgil, M.; Guha, R. This Fissured Land: An Ecological History of India; Oxford University Press: Delhi, India, 1992.

36. Park, G. Nga Uruora: The Groves of Life: Ecology and History in a New Zealand Landscape; Victoria University Press: Wellington, New Zealand, 1995.

37. Shiva, V. Staying Alive: Women, Ecology and Development; Zed Books: London, UK, 1989.

38. Kreike, E. Environmental Infrastructure in African History: Examining the Myth of Natural Resource Management in Namibia; Cambridge University Press: Cambridge, UK, 2003.

39. Van der Straeten, J.; Hasenöhrl, U. Connecting the Empire: New Research Perspectives on Infrastructures and the Environment in the (Post)Colonial World. NTM 2016, 24, 355-391. [CrossRef]

40. Ferguson, N. Civilization: The West and the Rest; Allen Lane: London, UK, 2011.

41. Kanth, R.K. (Ed.) The Challenge of Eurocentrism: Global Perspectives, Policy, and Prospects; Palgrave Macmillan: New York, NY, USA, 2009.

42. Said, E.W. Orientalism; Pantheon Books: New York, NY, USA, 1978.

43. Arnold, D. Everyday Technology: Machines and the Making of India's Modernity; University of Chicago Press: Chicago, IL, USA, 2013.

44. Needham, J. (Ed.) Science and Civilisation in China; Cambridge University Press: Cambridge, UK, 1954.

45. Brockway, L. Science and Colonial Expansion: The Role of the British Royal Botanical Gardens; Academic Press: New York, NY, USA, 1979.

46. Carney, J.A. Black Rice: The African Origins of the Rice Cultivation in the Americas; Harvard University Press: Cambridge, MA, USA, 2002.

47. MacLeod, R.M.; Lewis, M. (Eds.) Disease, Medicine and Empire: Perspectives on Western Medicine and the Experience of European Expansion; Routledge: London, UK; New York, NY, USA, 1988.

48. Schiebinger, L. Prospecting for Drugs. European Naturalists in the West Indies [2005]. In The Postcolonial Science and Technology Studies Reader; Harding, S., Ed.; Duke University Press: Durham, NC, USA, 2011; pp. 110-126.

49. Tilley, H. Africa as a Living Laboratory: Empire, Development, and the Problem of Scientific Knowledge, 1870-1950; University of Chicago Press: Chicago, IL, USA, 2011.

50. Fourchard, L. Between World History and State Formation: New Perspectives on Africa's Cities. J. Afr. Hist. 2011, 52, 223-248. [CrossRef]

51. Choi, H. The Social Construction of Imported Technologies: Reflections on the Social History of Technology in Modern Korea. Technol. Cult. 2017, 58, 905-920. [CrossRef] [PubMed]

52. Cooper, F. Kolonialismus denken: Konzepte und Theorien in kritischer Perspektive; Campus: Frankfurt, Germany, 2012.

53. Philips, J.E. (Ed.) Writing African History; Boydell \& Brewer: Rochester, NY, USA, 2005.

54. Werner, H. The Politics of Dams: Developmental Perspectives and Social Critique in Modern India; Oxford University Press: New Delhi, India, 2015.

55. Cooper, B.M. Oral Sources and the Challenge of African History. In Writing African History; Philips, J.E., Ed.; Boydell \& Brewer: Rochester, NY, USA, 2005; pp. 191-216.

56. Falola, T.; Jennings, C. (Eds.) Sources and Methods in African History: Spoken, Written, Unearthed; University of Rochester Press: Rochester, NY, USA, 2003.

57. White, L.; Miescher, S.F.; Cohen, D.W. (Eds.) African Words, African Voices: Critical Practices in Oral History; Indiana University Press: Bloomington, IN, USA, 2002.

58. Akallah, J.A.; Hård, M. Under the Historian's Radar: Local Water Supply Practices in Nairobi, 1940-1980. Water Alternatives 2020, 13, 886-901.

59. Hecht, G. Being Nuclear: Africans and the Global Uranium Trade; MIT Press: Cambridge, MA, USA, 2012.

60. Osseo-Asare, A. Atomic Junction: Nuclear Power in Africa after Independence; University of Chicago Press: Chicago, IL, USA, 2019.

61. White, L. Speaking with Vampires: Rumor and History in Colonial Africa; University of California Press: Berkeley, CA, USA, 2000.

62. Pernau, M. Global history: Wegbereiter für einen neuen Kolonialismus? Connections 2004. Available online: www.connections. clio-online.net/article/id/artikel-572 (accessed on 27 July 2021).

63. Eckert, A. Scenes from a Marriage: African History and Global History. Comparativ 2019, $29,36-51$.

64. Bray, F. Internationalization and the Art of Translation. Technol. Cult. 2017, 58, 815-834. [CrossRef]

65. Wenzlhuemer, R. Connections in Global History. Comparativ 2019, 29, 106-121.

66. Basalla, G. The Spread of Western Science. Science 1967, 156, 611-622. [CrossRef] [PubMed] 
67. Friedel, R.D. A Culture of Improvement: Technology and the Western Millennium; MIT Press: Cambridge, MA, USA, 2007.

68. Grewe, B.S. Raum und Macht: Eine Stoffgeschichte des Goldes im frühen 20. Jahrhundert. Jahrb. für Wirtsch. 2016, 57, 59-90. [CrossRef]

69. Andersen, C. British Engineers and Africa, 1875-1914; Pickering \& Chatto: London, UK, 2011.

70. Beattie, J.; Melillo, E.; O'Gorman, E. (Eds.) Eco-Cultural Networks and the British Empire: New Views on Environmental History; Bloomsbury: London, UK, 2015.

71. Bennett, B.M.; Hodge, J.M. (Eds.) Science and Empire: Knowledge and Networks of Science across the British Empire, 1800-1970; Palgrave Macmillan: Basingstoke, UK, 2011.

72. Lester, A. Imperial Circuits and Networks: Geographies of the British Empire. History Compass 2006, 4, 124-141. [CrossRef]

73. Magee, G.B.; Thompson, A.S. Empire and Globalisation: Networks of People, Goods and Capital in the British World, 1850-1914; Cambridge University Press: Cambridge, UK, 2010.

74. Lambert, D.; Lester, A. Colonial Lives across the British Empire: Imperial Careering in the Long Nineteenth Century; Cambridge University Press: Cambridge, UK, 2006.

75. Conrad, S. Globalgeschichte: Eine Einführung; C.H. Beck: Munich, Germany, 2013.

76. Epple, A. Globale Machtverhältnisse, lokale Verflechtungen: Die Berliner Kongokonferenz, Solingen und das Hinterland des kolonialen Waffenhandels. In Ränder der Moderne; Dejung, C., Lengwiler, M., Eds.; Böhlau: Cologne, Germany, 2016 ; pp. 65-91.

77. Hausman, W.J.; Hertner, P.; Wilkins, M. Global Electrification: Multinational Enterprise and International Finance in the History of Light and Power, 1878-2007; Cambridge University Press: Cambridge, UK, 2008.

78. Hodge, J.M. Triumph of the Expert: Agrarian Doctrines of Development and the Legacies of British Colonialism; Ohio University Press: Athens, OH, USA, 2007.

79. Home, R. Of Planting and Planning: The Making of British Colonial Cities; Routledge: London, UK, 2013.

80. Prior, C. Exporting Empire: Africa, Colonial Officials and the Construction of the British Imperial State, c. 1900-39; Manchester University Press: Manchester, UK, 2013.

81. Sunderland, D. Managing British Colonial and Post-Colonial Development: The Crown Agents, 1914-1974; Boydell \& Brewer: Suffolk, UK, 2007.

82. Baumann, C.; Dietze, A.; Maruschke, M. Portals of Globalization. An Introduction. Z. Glob. Vgl. Geschichtsforschung 2017, 27, 7-20.

83. Heerten, L. Ankerpunkte der Verflechtung: Hafenstädte in der neueren Globalgeschichtsschreibung. Gesch. Ges. 2017, 43, 146-175. [CrossRef]

84. Hunt, T. Ten Cities that Made an Empire; Penguin: Milton Keynes, UK, 2015.

85. Pratt, M.L. Arts of the Contact Zone. Profession 1991, 33-40.

86. Galison, P. Image and Logic: A Material Culture of Microphysics; University of Chicago Press: Chicago, IL, USA, 1997.

87. Hård, M.; Tjoa-Bonatz, M.L. Trading Zones in a Colony: Transcultural Techniques at Missionary Stations in the Dutch East Indies, 1860-1940. Soc. Stud. Sci. 2020, 50, 932-955. [CrossRef] [PubMed]

88. Fischer-Kattner, A.; Kopf, M.; Spies, E.; Holtz, M. Introduction. Z. Glob. Vgl. Geschichtsforschung 2018, $28,7-21$.

89. Beattie, J.; Morgan, R. Engineering Edens on this 'Rivered Earth'? A Review Article on Water Management and Hydro-Resilience in the British Empire, 1860s-1940s. Environ. Hist. 2017, 23, 39-63. [CrossRef]

90. Broich, J. Engineering the Empire: British Water Supply Systems and Colonial Societies, 1850-1900. J. Br. Stud. 2007, 46, 346-365. [CrossRef]

91. Osseo-Asare, A. Bitter Roots: The Search for Healing Plants in Africa; University of Chicago Press: Chicago, IL, USA, 2014.

92. Hawthorne, W. The Cultural Meaning of Work: The "Black Rice Debate" Reconsidered. In Rice: Global Networks and New Histories; Bray, F., Coclanis, P.A., Fields-Black, E.L., Schäfer, D., Eds.; Cambridge University Press: Cambridge, UK, 2015 ; pp. $279-290$.

93. Möllers, N.; Dewalt, B. (Eds.) Objects in Motion: Globalizing Technology; Smithsonian Institution Scholarly Press: Washington, DC, USA, 2016.

94. Trentmann, F. Empire of Things: How We Became a World of Consumers, from the Fifteenth Century to the Twenty-First; Allen Lane: London, UK, 2016.

95. Crosby, A.W. The Columbian Exchange: Biological and Cultural Consequences of 1492; Greenwood Publication Company: Westport, CT, USA, 1972.

96. McNeill, J.R. Biological Exchange in Global Environmental History. In A Companion to Global Environmental History; McNeill, J.R., Mauldin, E.S., Eds.; Wiley-Blackwell: Chichester, UK, 2012; pp. 433-451.

97. Latour, B. Eine neue Soziologie für eine neue Gesellschaft: Einführung in die Akteur-Netzwerk-Theorie; Suhrkamp: Frankfurt, Germany, 2007.

98. Gerstenberger, D.; Glasman, J. Globalgeschichte mit Maß: Was Globalhistoriker von der Akteur-Netzwerk-Theorie lernen können“. In Techniken der Globalisierung: Globalgeschichte Meets Akteur-Netzwerk-Theorie; Gerstenberger, G., Glasman, J., Eds.; Transcript: Bielefeld, Germany, 2016; pp. 11-40.

99. Schulze, F. ANT und Globalgeschichte: Ein erster Eindruck. In Techniken der Globalisierung: Globalgeschichte meets Akteur-NetzwerkTheorie; Gerstenberger, G., Glasman, J., Eds.; transcript: Bielefeld, Germany, 2016; pp. 281-290.

100. Shamir, R. Current Flow: The Electrification of Palestine; Stanford University Press: Palo Alto, CA, USA, 2013.

101. Kalb, M. Naturalizing Trout? Fish Farming in German Southwest Africa. Environ. Soc. Portal Arcadia 2017, 33. [CrossRef]

102. Mintz, S.W. Sweetness and Power: The Place of Sugar in Modern History; Viking Penguin: New York, NY, USA, 1985.

103. Beckert, S. King Cotton: Eine Geschichte des globalen Kapitalismus; C. H. Beck: Munich, Germany, 2014. 
104. Grewe, B.S. Gold: Eine Weltgeschichte; C.H. Beck: Munich, Germany, 2019.

105. Riello, G.; Parthasarathi, P. (Eds.) The Spinning World: A Global History of Cotton Textiles, 1200-1850; Oxford University Press: Oxford, UK, 2009.

106. Weber, H. Urbanisierung und Umwelt: Ein Plädoyer für den Blick auf Materialitäten, Ressourcen und urbane Metabolismen. Inf. Mod. Stadtgesch. 2012, 2, 28-35.

107. Robbins, B. Commodity Histories. PMLA 2005, 120, 454-463. [CrossRef]

108. Bair, J. (Ed.) Frontiers of Commodity Chain Research; Stanford University Press: Palo Alto, CA, USA, 2009.

109. Evenden, M. Aluminum, Commodity Chains, and the Environmental History of the Second World War. Environ. Hist. 2011, 16, 69-93. [CrossRef]

110. Quark, A.A. Toward a New Theory of Change: Socio-Natural Regimes and the Historical Development of the Textiles Commodity Chain. Rev. A J. Fernand Braudel Center Study Econ. Hist. Syst. Civiliz. 2008, 31, 1-37.

111. Arnold, D. Burning Issues: Cremation and Incineration in Modern India. NTM 2016, 24, 393-419. [CrossRef]

112. Musso, M. Energy Imperialism? Introduction to the Special Issue. J. Energy Hist. 2020, 3. Available online: energyhistory.eu/en/ node/205 (accessed on 15 June 2021).

113. Mitchell, T. Carbon Democracy: Political Power in the Age of Oil; Verso: London, UK, 2011.

114. Hasenöhrl, U.; Meyer, J.-H. The Energy Challenge in Historical Perspective. Technol. Cult. 2020, 61, 295-306. [CrossRef] [PubMed]

115. Mavhunga, C.C.; Trischler, H. (Eds.) Energy and Colonialism, Energy (In)Dependence: Africa, Europe, Greenland, North America; RCC Perspectives, Vol. 5; RCC: Munich, Germany, 2014.

116. Allen, R.C. Why was the Industrial Revolution British? Oxonomics 2009, 4, 50-54. [CrossRef]

117. Pomeranz, K. The Great Divergence: China, Europe and the Making of the Modern World Economy; Princeton University Press: Princeton, NJ, USA, 2000.

118. Barak, O. Powering Empire: How Coal Made the Middle East and Sparked Global Carbonization; University of California Press: Berkeley, CA, USA, 2020.

119. Graf, R. Oil and Sovereignty: Petro-Knowledge and Energy Policy in the United States and Western Europe in the 1970s; Berghahn: New York, NY, USA, 2018.

120. Painter, D.S. Oil and the American Century: The Political Economy of U.S. Foreign Oil Policy, 1941-1954; Johns Hopkins University Press: Baltimore, MD, USA, 1986.

121. Smil, V. Energy Transitions: History, Requirements, Prospects; Praeger: Santa Barbara, CA, USA, 2010.

122. Steffen, W.; Crutzen, P.J.; McNeill, J.R. The Anthropocene: Are Humans Now Overwhelming the Great Forces of Nature? Ambio 2007, 36, 614-621. [CrossRef]

123. Malm, A. Fossil Capital: The Rise of Steam-Power and the Roots of Global Warming; Verso: London, UK, 2016.

124. Ottinger, G. The Winds of Change: Environmental Justice in Energy Transitions. Sci. Cult. 2013, 22, 222-229. [CrossRef]

125. Cronon, W. Nature's Metropolis: Chicago and the Great West; W. W. Norton: New York, NY, USA; London, UK, 1991.

126. Barles, S. Feeding the City: Food Consumption and Flow of Nitrogen, Paris, 1801-1914. Sci. Total Environ. 2007, 375, 48-58. [CrossRef]

127. Krausmann, F.; Lauk, C.; Haas, W.; Wiedenhofer, D. From Resource Extraction to Outflows of Wastes and Emissions: The Socioeconomic Metabolism of the Global Economy, 1900-2015. Glob. Environ. Chang. 2018, 52, 131-140. [CrossRef]

128. De Molina, G.; Toledo, M. The Social Metabolism: A Socio-Ecological Theory of Historical Change; Springer: Cham, Germany, 2015.

129. Schott, D.; Luckin, B.; Massard-Guilbaud, G. (Eds.) Resources of the City: Contributions to an Environmental History of Modern Europe; Ashgate: Aldershot, UK, 2005.

130. Boyden, S.; Millar, S.; Newcombe, K.; O’Neill, B. The Ecology of the City and its People: The Case of Hong Kong; Australian National University Press: Canberra, Australia, 1981.

131. Infante-Amate, J.; Krausmann, F. Trade, Ecologically Unequal Exchange and Colonial Legacy: The Case of France and its Former Colonies (1962-2015). Ecol. Econ. 2019, 156, 98-109. [CrossRef]

132. Kneitz, A. German Water Infrastructures in China: Colonial Qingdao 1898-1914. NTM 2016, 24, 421-450. [CrossRef]

133. Weber, H. Material Flows and Circular Thinking. In Concepts of Urban-Environmental History; Haumann, S., Knoll, M., Mares, D., Eds.; Transcript: Bielefeld, Germany, 2020; pp. 125-143.

134. Osterhammel, J. Die Verwandlung der Welt: Eine Geschichte des 19. Jahrhunderts; C.H. Beck: Munich, Germany, 2011.

135. Rosenberg, E.S. (Ed.) 1870-1945: Weltmärkte und Weltkriege; Geschichte der Welt, Vol. 5; C.H. Beck; Harvard Up: Munich, Germany, 2012.

136. Engels, J.I.; Schenk, G.J. Infrastrukturen der Macht-Macht der Infrastrukturen; Überlegungen zu einem Forschungsfeld. Hist. Z. 2014, Beiheft 63, 22-58.

137. McFarlane, C. Governing the Contaminated City: Infrastructure and Sanitation in Colonial and Post-Colonial Bombay. Int. J. Urban Reg. Res. 2008, 32, 415-435. [CrossRef]

138. Yepes, T.; Pierce, J.; Foster, V. Making Sense of Africa's Infrastructure Endowment: A Benchmarking Approach; Policy Research Working Paper, no. WPS 4912; World Bank: Washington, DC, USA, 2009.

139. Nilsson, D. The Unseeing State: How Ideals of Modernity Have Undermined Innovation in Africa's Urban Water Systems. NTM 2016, 24, 481-510. [CrossRef] [PubMed]

140. Hampf, M.M.; Müller-Pohl, S. (Eds.) Global Communication Electric: Business, News and Politics in the World of Telegraphy; Campus: Frankfurt, Germany; New York, NY, USA, 2013. 
141. Headrick, D.R. The Tentacles of Progress: Technology Transfer in the Age of Imperialism, 1850-1940; Oxford University Press: New York, NY, USA, 1988.

142. Van Laak, D. Imperiale Infrastruktur: Deutsche Planungen für eine Erschließung Afrikas 1880 bis 1960; Schöningh: Paderborn, Germany, 2004.

143. Müller, S.M. Wiring the World: The Social and Cultural Creation of Global Telegraph Networks; Columbia University Press: New York, NY, USA, 2016.

144. Wenzlhuemer, R. Connecting the Nineteenth-Century World: The Telegraph and Globalization; Cambridge University Press: Cambridge, UK, 2013.

145. Castryck, G. (Ed.) From Railway Juncture to Portal of Globalization: Making Globalization Work in African and South Asian Railway Towns; Leipziger Universitätsverlag: Leipzig, Germany, 2015.

146. Monson, J. Africa's Freedom Railway: How a Chinese Project Changed Lives and Livelihoods in Tanzania; Indiana University Press: Bloomington, IN, USA, 2009.

147. Whang, P.Y. Regional Derailments: The Saga of the East African Railways. J. East. Afr. Stud. 2018, 12, 716-734. [CrossRef]

148. Barak, O. Scraping the Surface: The Techno-Politics of Modern Streets in Turn-of-Twentieth-Century Alexandria. Mediterr. Hist. Rev. 2015, 24, 187-205. [CrossRef]

149. Freed, L. Networks of (Colonial) Power: Roads in French Central Africa after World War I. Hist. Technol. 2010, 25, 203-225. [CrossRef]

150. Gewald, J.-B.; Luning, S.W.J.; Van Walraven, K. (Eds.) The Speed of Change: Motor Vehicles and People in Africa, 1890-2000; Brill: Leiden, The Netherlands, 2009.

151. Grace, J. Heroes of the Road: Road, Gender, and the Politics of Mobility in Twentieth-Century Tanzania. Afr. J. Int. Afr. Inst. 2013, 83, 403-425. [CrossRef]

152. Gwilliam, K. Africa's Transport Infrastructure: Mainstreaming Maintenance and Management; World Bank: Washington, DC, USA, 2011.

153. Hart, J. Ghana on the Go: African Mobility in the Age of Motor Transportation; Indiana University Press: Bloomington, IN, USA, 2016.

154. Hart, J. Of Pirate Drivers and Honking Horns: Mobility, Authority, and Urban Planning in Late-Colonial Accra. Technol. Cult. 2020, 61, S49-S76. [CrossRef]

155. Beck, K.; Klaeger, G.; Stasik, M. (Eds.) The Making of the African Road; Brill: Leiden, The Netherlands, 2017.

156. Chikowero, M. Subalternating Currents: Electrification and Power Politics in Bulawayo, Colonial Zimbabwe, 1894-1939. J. South. Afr. Stud. 2007, 33, 287-306. [CrossRef]

157. Hasenöhrl, U. Rural Electrification in the British Empire. Hist. Retail. Consum. 2018, 4, 10-27. [CrossRef]

158. McDonald, D.A. (Ed.) Electric Capitalism: Recolonising Africa on the Power Grid; earthscan: London, UK, 2009.

159. Winther, T. The Impact of Electricity: Development, Desires and Dilemmas; Berghahn: New York, NY, USA, 2011.

160. Bigon, L. A History of Urban Planning in Two West African Colonial Capitals: Residential Segregation in British Lagos and French Dakar (1850-1930); Edwin Mellen Press: Lewiston, NY, USA, 2009.

161. Cockéry-Vidrovitch, C. From Residential Segregation to African Urban Centres: City Planning and the Modalities of Change in Africa South of the Sahara. J. Contemp. Afr. Stud. 2014, 32, 1-12. [CrossRef]

162. Gandy, M. Planning, Anti-Planning and the Infrastructure Crisis Facing Metropolitan Lagos. Urban Stud. 2006, 43, 371-396. [CrossRef]

163. Hege, P. The German Variation: A Sketch of Colonial Städtebau in Africa ca. 1884-1919. In Urban Planning in Sub-Saharan Africa: Colonial and Postcolonial Planning Cultures; Silva, C.N., Ed.; Routledge: New York, NY, USA, 2015; pp. $165-179$.

164. Home, R.; King, A.D. Urbanism and Master Planning: Configuring the Colonial City. In Architecture and Urbanism in the British Empire; Bremner, G.A., Ed.; Oxford University Press: Oxford, UK, 2016; pp. 51-85.

165. Mutongi, K. Matatu: A History of Popular Transportation in Nairobi; University of Chicago Press: Chicago, IL, USA, 2017.

166. Swanson, M.W. The Sanitation Syndrome: Bubonic Plague and Urban Native Policy in the Cape Colony. J. Afr. Hist. 1977, 18, 387-410. [CrossRef] [PubMed]

167. Beeckmans, L. Editing the African City: Reading Colonial Planning in Africa from a Comparative Perspective. Plan. Perspect. 2013, 28, 615-627. [CrossRef]

168. Coutard, O.; Rutherford, J. (Eds.) Beyond the Networked City: Infrastructure Reconfigurations and Urban Change in the North and South; Routledge: London, UK, 2016.

169. Monstadt, J.; Schramm, S. Beyond the Networked City? Suburban Constellations in Water and Sanitation Systems. In Suburban Constellations. Governance, Land and Infrastructure in the 21st Century; Keil, R., Ed.; Jovis: Berlin, Germany, 2013 ; pp. 85-94.

170. Silva, C.N. (Ed.) Urban Planning in Sub-Saharan Africa: Colonial and Postcolonial Planning Cultures; Routledge: New York, NY, USA, 2015.

171. Hughes, T.P. Networks of Power: Electrification in Western Society 1880-1930; Johns Hopkins University Press: Baltimore, MD, USA, 1983.

172. Hughes, T.P. The Evolution of Large Technological Systems. In The Social Construction of Technological Systems: New Directions in the Sociology and History of Technology; Bijker, W.E., Hughes, T.P., Pinch, T., Eds.; MIT Press: Cambridge, MA, USA, $1989 ;$ pp. 51-82.

173. Mavhunga, C.C. Preface. In What Do Science, Technology, and Innovation Mean from Africa? Mavhunga, C.C., Ed.; MIT Press: Cambridge, MA, USA; London, UK, 2017.

174. Mavhunga, C.C. Introduction. In What Do Science, Technology, and Innovation Mean from Africa? Mavhunga, C.C., Ed.; MIT Press: Cambridge, MA, USA; London, UK, 2017; pp. 1-27.

175. König, W. Technikgeschichte: Eine Einführung in ihre Konzepte und Forschungsergebnisse; Franz Steiner: Stuttgart, Germany, 2009. 
176. Sovacool, B.K.; Hess, D.J.; Amir, S.; Geels, F.W.; Hirsh, R.; Medina, L.R.; Miller, C.; Palavicino, C.A.; Phadke, R.; Ryghaug, M.; et al. Sociotechnical Agendas: Reviewing Future Directions for Energy and Climate Research. Energy Res. Soc. Sci. 2020, $70,101617$. [CrossRef]

177. Moss, T. Socio-technical Change and the Politics of Urban Infrastructure: Managing Energy in Berlin between Dictatorship and Democracy. Urban Stud. 2014, 51, 1432-1448. [CrossRef]

178. Van der Vleuten, E. Toward a Transnational History of Technology: Meanings, Promises, Pitfalls. Technol. Cult. 2008, 49, 974-994. [CrossRef]

179. Carse, A. Nature as Infrastructure: Making and Managing the Panama Canal Watershed. Soc. Stud. Sci. 2012, 42, 539-563. [CrossRef]

180. Nyanchaga, E.N. History of Water Supply and Governance in Kenya (1895-2005): Lessons and Futures; Tampere University Press: Tampere, Finland, 2016.

181. Frank, S.; Gandy, M. (Eds.) Hydropolis: Wasser und die Stadt der Moderne; Campus: Frankfurt, Germany, 2006.

182. Graham, S. (Ed.) Disrupted Cities: When Infrastructure Fails; Routledge: New York, NY, USA, 2009.

183. Graham, S.; Marvin, S. Splintering Urbanism: Networked Infrastructures, Technological Mobilities and the Urban Condition; Routledge: London, UK, 2001.

184. Akallah, J.A. Technologies from Below: Water and Sanitation Supply in Nairobi's Informal Settlements. Technol. Stories 2020, 8. [CrossRef]

185. Eckert, A. Lagos im 20. Jahrhundert: Informalität als urbanes Prinzip. In Megastädte im 20. Jahrhundert; Schwentker, W., Ed.; V\&R: Göttingen, Germany, 2006; pp. 238-256.

186. McFarlane, C.; Waibel, M. (Eds.) Urban Informalities: Reflections on the Formal and Informal; Ashgate: Farnham, UK, 2012.

187. Myers, G. African Cities: Alternative Visions of Urban Theory and Practice; Zed Books: London, UK, 2011.

188. Parnell, S.; Oldfield, S. (Eds.) The Routledge Handbook on Cities of the Global South; Routledge: London, UK, 2014.

189. Larkin, B. Ambient Infrastructures: Generator Life in Nigeria. Technosphere Mag. 2016. Available online: https://technospheremagazine.hkw.de/p/Ambient-Infrastructures-Generator-Life-in-Nigeria-fCgtKng7vpt7otmky9vnFw (accessed on 27 July 2021).

190. Gupta, A. An Anthropology of Electricity from the Global South. Cult. Anthropol. 2015, 30, 555-568. [CrossRef]

191. Schnitzler, A. von. Travelling Technologies: Infrastructure, Ethical Regimes, and the Materiality of Politics in South Africa. Cult. Anthropol. 2013, 28, 670-693. [CrossRef]

192. World Bank. Bringing Electricity to Kenya's Slums: Hard Lessons Lead to Great Gains. 2015. Available online: https://www. worldbank.org/en/news/feature/2015/08/17/bringing-electricity-to-kenyas-slums-hard-lessons-lead-to-great-gains (accessed on 27 July 2021).

193. Larkin, B. Pirate Infrastructures. In Network/Netplay: Structures of Participation in Digital Culture; Karaganis, J., Jeremijenko, N., Eds.; Duke University Press: Durham, NC, USA, 2005; pp. 74-84.

194. Mavhunga, C.C. Transient Workspaces: Technologies of Everyday Innovation in Zimabwe; MIT Press: Cambridge, MA, USA, 2014.

195. Silver, J. Incremental Infrastructures: Material Improvisation and Social Collaboration across Post-Colonial Accra. Urban Geogr. 2014, 35, 788-804. [CrossRef]

196. Terreni Brown, S. Kampala's Sanitary Regime: Whose Toilet Is It anyway? In Infrastructural Lives: Urban Infrastructure in Context; Graham, S., McFarlane, C., Eds.; Routledge: London, UK; New York, NY, USA, 2014; pp. 153-173.

197. Edgerton, D. The Shock of the Old: Technology and Global History since 1900; Oxford University Press: Oxford, UK, 2007.

198. Jackson, S.J. Thinking Repair. In Media Technologies: Essays on Communication, Materiality and Society; Gillespie, T., Boczkowski, P.J., Foot, K.A., Eds.; MIT Press: Cambridge, MA, USA, 2014; pp. 221-239.

199. Larkin, B. The Politics and Poetics of Infrastructure. Annu. Rev. Anthropol. 2013, 42, 327-343. [CrossRef]

200. Simone, A. People as Infrastructure: Intersecting Fragments in Johannesburg. Public Cult. 2004, 16, 407-429. [CrossRef]

201. Taylor, A. On Simone's “People as Infrastructure". Blogpost 2013. Available online: https://ast.io/reading-simones-peopleinfrastructure/ (accessed on 27 July 2021).

202. Edyedi, T.M.; Mehos, D.C. (Eds.) Inverse Infrastructures: Disrupting Networks from Below; Edward Elgar Publishing: Cheltenham, UK; Northampton, MA, USA, 2012.

203. Edwards, P.N. Infrastructure and Modernity: Force, Time, and Social Organization in the History of Sociotechnical Systems. In Modernity and Technology; Misa, T.J., Brey, P., Feenberg, A., Eds.; Cambridge University Press: Cambridge, UK, 2003 ; pp. 185-225.

204. D'Souza, R. Drowned and Dammed: Colonial Capitalism and Flood Control in Eastern India; Oxford University Press: Oxford, UK, 2006.

205. Zeller, T. Aiming for Control, Haunted by its Failure: Towards an Envirotechnical Understanding of Infrastructures. Glob. Environ. 2017, 10, 202-228. [CrossRef]

206. Christmann, G.B.; Ibert, O.; Kilper, H.; Moss, T. Vulnerability and Resilience from a Socio-Spatial Perspective: Towards a Theoretical Framework; IRS Working Paper no. 45; Leibniz-Institute for Research on Society and Space (IRS): Erkner, Germany, 2012; Available online: http: / /hdl.handle.net/10419/228575 (accessed on 27 July 2021).

207. Engels, J.I. (Ed.) Key Concepts for Critical Infrastructure Research; Springer: Wiesbaden, Germany, 2018.

208. Janssen, M.A.; Ostrom, E. Resilience, Vulnerability, and Adaption: A Cross-Cutting Theme of the international Human Dimensions Programme on Global Environmental Change. Glob. Environ. Chang. 2006, 16.

209. UNFCCC (United Nations Framework Convention on Climate Change). Climate Change: Impacts, Vulnerabilities and Adaption in Developing Countries; UNFCCC: Bonn, Germany, 2007. 
210. Diogo, M.P.; Van Laak, D. Europeans Globalizing: Mapping, Exploiting, Exchanging; Palgrave Macmillan: London, UK, 2016.

211. Thomas, L.M. Historicising Agency. Gender Hist. 2016, 28, 324-339. [CrossRef]

212. Bassett, R. The Technological Indian; Harvard University Press: Cambridge, MA, USA, 2016.

213. Harding, S.G. (Ed.) The Postcolonial Science and Technology Studies Reader; Duke University Press: Durham, DC, USA, 2011.

214. MacLeod, R.M. Nature and Empire: Science and the Colonial Enterprise; University of Chicago Press: Chicago, IL, USA, 2000.

215. Moon, S. Place, Voice, Interdisciplinarity: Understanding Technology in the Colony and Postcolony. Hist. Technol. 2010, 26, 189-201. [CrossRef]

216. Sangwan, S. Science, Technology and Colonisation: An Indian Experience, 1757-1857; Anamika Prakashan: Delhi, India, 1991.

217. Hecht, G. (Ed.) Entangled Geographies: Empire and Technopolitics in the Global Cold War; MIT Press: Cambridge, MA, USA, 2011.

218. Meiton, F. The Radiance of the Jewish National Home: Technocapitalism, Electrification, and the Making of Modern Palestine. Comp. Stud. Soc. Hist. 2015, 57, 975-1006. [CrossRef]

219. Mitchell, T. Rule of Experts: Egypt, Techno-Politics, Modernity; University of California Press: Berkeley, CA, USA, 2002.

220. Plageman, N. "Accra is Changing, Isn't It?": Urban Infrastructure, Independence, and Nation in the Gold Coast's Daily Graphic, 1954-1957. Int. J. Afr. Hist. Stud. 2010, 43, 137-159.

221. Bloom, P.J.; Miescher, S.F.; Manuh, T. (Eds.) Modernization as Spectacle in Africa; Indiana University Press: Bloomington, IN, USA, 2014.

222. Ferguson, J. Expectations of Modernity: Myths and Meanings of Urban Life on the Zambian Copperbelt; University of California Press: Berkeley, CA, USA, 1999.

223. Prestel, J.B. Emotional Cities: Debates on Urban Change in Berlin and Cairo, 1860-1910; Oxford University Press: Oxford, UK, 2017.

224. Miescher, S.F.; Tsikata, D. Hydro-Power and the Promise of Modernity and Development in Ghana: Comparing the Akosombo and Bui Dam Projects. Ghana Stud. 2009, 10, 15-53. [CrossRef]

225. Brown, M.G. Khartoum at Night: Fashion and Body Politics in Imperial Sudan; Stanford University Press: Stanford, CA, USA, 2017.

226. Serlin, D. Confronting African Histories of Technology: A Conversation with Keith Breckenridge and Gabrielle Hecht. Radic. Hist. Rev. 2017, 127, 87-102. [CrossRef]

227. Hahn, H.P. (Ed.) Consumption in Africa: Anthropological Approaches; Lit: Münster, Germany, 2008.

228. Mamidipudi, A.; Shyamasundari, B.; Bijker, W.E. Mobilising Discourses: Handloom as Sustainable Socio-Technology. Econ. Political Wkly. 2012, 47, 41-51.

229. Murillo, B. Market Encounters: Consumer Culture in Twentieth Century Ghana; Ohio University Press: Athens, OH, USA, 2017.

230. Posel, D.; Van Wyk, I. (Eds.) Conspicuous Consumption in Africa; Wits University Press: Johannesburg, South Africa, 2019.

231. Ross, R.; Hinfelaar, M.; Peša, I. (Eds.) The Objects of Life in Central Africa: The History of Consumption and Social Change, 1840-1980; Brill: Leiden, The Netherlands, 2013.

232. Edward, F.; Hård, M. Maintaining the Local Empire: The Public Works Department in Dar es Salaam, 1920-1960. J. Transp. Hist. 2020, 41, 27-46. [CrossRef]

233. Mika, M. The Half-Life of Radiotherapy and Other Transferred Technologies. Technol. Cult. 2020, 61, S135-S157. [CrossRef]

234. Krebs, S.; Schabacher, G.; Weber, H. (Eds.) Kulturen des Reparierens: Dinge-Wissen-Praktiken; Transcript: Bielefeld, Germany, 2017.

235. Edgerton, D. Creole Technologies and Global Histories: Rethinking how Things Travel in Space and Time. Hist. Sci. Technol. J. 2008, 1, 75-112.

236. Morton, D. Age of Concrete: Housing and the Shape of Aspiration in the Capital of Mozambique; Ohio University Press: Athens, OH, USA, 2019.

237. Beinart, W. African History and Environmental History. Afr. Aff. 2000, 99, 269-302. [CrossRef]

238. Blocher, E. Der Wasserbau-Staat: Die Transformation des Nils und das moderne Ägypten 1882-1971; Ferdinand Schöningh: Paderborn, Germany, 2016.

239. Dumett, R.E. Imperialism, Economic Development and Social Change in West Africa; Carolina Academic Press: Durham, NC, USA, 2013.

240. Isaacman, A.F.; Roberts, R. (Eds.) Cotton, Colonialism, and Social History in Sub-Saharan Africa; Heinemann: Portsmouth, NH, USA, 1995.

241. Neumann, R.P. Imposing Wilderness: Struggles over Livelihood and Nature Preservation in Africa; University of California Press: Berkley, CA, USA, 1998.

242. DeLoughrey, E.; Didur, J.; Carrigan, A. (Eds.) Global Ecologies and the Environmental Humanities: Postcolonial Approaches; Routledge: New York, NY, USA, 2015.

243. Johnson, S. (Ed.) Indigenous Knowledge; White Horse Press: Cambridge, UK, 2012.

244. Leach, M.; Mearns, R. (Eds.) The Lie of the Land: Challenging Received Wisdom on the African Environment; Heinemann: Portsmouth, NH, USA, 1996.

245. Maddox, G.; Kimambo, I.N.; Giblin, J.L. Custodians of the Land: Ecology and Culture in the History of Tanzania; Ohio University Press: Athens, OH, USA, 1996.

246. Tischler, J.; Haltermann, I. (Eds.) Environmental Change and African Societies; Brill: Leiden, The Netherlands, 2019.

247. Beinart, W.; McGregor, J. (Eds.) Social History and African Environments; James Currey: Oxford, UK, 2014.

248. Kwashirai, V.C.; Environmental History of Africa. Encyclopedia of Life Support Systems (EOLSS). Available online: http://www. eolss.net/Eolss-sampleAllChapter.aspx (accessed on 27 July 2021).

249. Kwashirai, V.C. Green Colonialism in Zimbabwe, 1890-1980; Cambria Press: Amherst, NY, USA, 2009.

250. McCann, J. Green Land, Brown Land, Black Land: An Environmental History of Africa, 1800-1990; Heinemann: Portsmouth, NH, USA, 1999. 
251. Carruthers, J. Environmental History with an African Edge. In The Edges of Environmental History: Honouring Jane Carruthers; Mauch, C., Robin, L., Eds.; RCC Perspectives; RCC: Munich, Germany, 2014; pp. 1-19.

252. Shanguhyia, M.S. Colonialism and the African Environment. In The Palgrave Handbook of African Colonial and Postcolonial History; Falola, T., Ed.; Palgrave Macmillan: New York, NY, USA, 2018; pp. 43-80.

253. Twagira, L.A. Machines that Cook or Women who Cook? Technol. Cult. 2020, 61, S77-S103. [CrossRef]

254. Bissell, W.C. Between Fixity and Fantasy: Assessing the Spatial Impact of Colonial Urban Dualism. J. Urban Hist. 2011, 37, 208-229. [CrossRef]

255. Beverley, E.L. Colonial Urbanism and South Asian Cities. Soc. Hist. 2011, 36, 482-497. [CrossRef]

256. Haynes, D.E.; Rao, N. Beyond the Colonial City: Re-Evaluating the Urban History of India, ca. 1920-1970. South Asia 2013, 36, 317-335. [CrossRef]

257. Lonsdale, J. Town Life in Colonial Kenya. Azania 2001, 36-37, 206-222. [CrossRef]

258. Aguiar, M. Tracking Modernity: India's Railway and the Culture of Mobility; University of Minnesota Press: Minneapolis, MN, USA, 2011.

259. Van Onselen, C. The Night Trains: Moving Mozambican Miners to and from South Africa, circa 1902-1955; Jonathan Ball: Johannesburg/Cape Town, South Africa, 2019.

260. Adebayo, A.D. African Agency and the Pre-History of Electrification in Lagos, c. 1860s-1896. In Proceedings of the Society for the History of Technology (SHOT) Annual Meeting, Milano, Italy, 25 October 2019.

261. Botha, C. People and the Environment in Colonial Namibia. S. Afr. Hist. J. 2005, 52, 170-190. [CrossRef]

262. Bray, F. Only Connect: Comparative, National, and Global History as Frameworks for the History of Science and Technology in Asia. East Asian Sci. Technol. Soc. 2012, 6, 233-241. [CrossRef]

263. Jones, E. The European Miracle: Environments, Economies and Geopolitics in the History of Europe and Asia; Cambridge University Press: Cambridge, UK, 1981.

264. Popplow, M. Technology and Technical Knowledge in the Debate about the "Great Divergence". Artefact 2016, 4, 275-285. Available online: http://journals.openedition.org/artefact/485 (accessed on 27 July 2021). [CrossRef]

265. Epple, A. Globalisierung/en, Version 1.0. Docupedia-Zeitgeschichte. 11 June 2012. Available online: https:/ / zeitgeschichte-digital. de/doks/frontdoor/index/index/docId/273 (accessed on 27 February 2021).

266. Ghobrial, J.-P.A. Introduction: Seeing the World like a Microhistorian. Past Present 2019, 242 (Suppl. S14), 1-22. [CrossRef]

267. Davis, N.Z. Decentering History: Local Stories and Cultural Crossings in a Global World. Hist. Theory 2011, 50, 188-202. [CrossRef]

268. Fischer-Tiné, H. Marrying Global History with South Asian History: Potential and Limits of Global Microhistory in a Regional Inflection. Comparativ 2019, 29, 52-77.

269. Levi, G. Frail Frontiers? Past Present 2019, 242 (Suppl. S14), 37-49. [CrossRef]

270. De Vries, J. Playing with Scales: The Global and the Micro, the Macro and the Nano. Past Present 2019, 242 (Suppl. S14), 23-36. [CrossRef]

271. Matin, K. Redeeming the Universal: Postcolonialism and the Inner Life of Eurocentricism. Eur. J. Int. Relat. 2013, 19, 353-377. [CrossRef]

272. Sarkar, T. How to Think Universalism from Colonial and Post Colonial Locations: Some Indian Efforts. COLLeGIUM 2008, 4. Available online: http:/ / hdl.handle.net/10138/25789 (accessed on 27 July 2021). 